\title{
Dostosowanie parametrów pracy PMG do aktualnych potrzeb rynku gazu ziemnego w Polsce
}

\author{
Adaptation of the UGS operating parameters to the current needs of the natural gas \\ market in Poland
}

\author{
Bogdan Filar, Mariusz Miziołek, Tadeusz Kwilosz \\ Instytut Nafty i Gazu - Państwowy Instytut Badawczy
}

\begin{abstract}
STRESZCZENIE: W publikacji poruszono problem dostosowania parametrów eksploatacji PMG do zmian zachodzących w polskim systemie gazowniczym. Podkreślono, że zapotrzebowanie na pojemność czynną magazynów bezpośrednio wynika z wielkości krajowego zużycia gazu ziemnego oraz ze struktury dostaw gazu na rynek. Na wykresie przedstawionym na rysunku 1 zaprezentowano zużycie gazu w Polsce, w rozbiciu na wydobycie krajowe i import, w latach 1995-2018. Przedstawiony wykres potwierdził szybki wzrost zapotrzebowania na gaz w ostatnich latach. Dodatkowo wykres pokazał, że począwszy od 2012 roku krajowe wydobycie gazu ziemnego systematycznie spadało - z wielkości 4,3 $\mathrm{mld} \mathrm{m}^{3}$ do 3,8 $\mathrm{mld} \mathrm{m}^{3}$. W związku z tym rosnące zapotrzebowanie na gaz jest zaspokajane dodatkowym jego importem. W roku 2018 wielkość importu gazu ziemnego wynosiła około 14,5 mld m³. Obecnie około 79\% całkowitego zużycia gazu pokrywane jest importem. W artykule podkreślono, że szybko rosnący import gazu generuje zapotrzebowanie na nowe pojemności czynne PMG. Głównym celem publikacji jest znalezienie odpowiedzi na pytanie, jakie parametry powinien posiadać nowo projektowany podziemny magazyn gazu, aby mógł spełnić obecne wymagania rynku gazowniczego w Polsce. W celu określenia pożądanych przez rynek parametrów PMG przeanalizowano koszty świadczenia usług magazynowania gazu w Polsce. Przeprowadzona analiza wykazała dużą rozpiętość tych kosztów. Generalnie wszystkie usługi magazynowania gazu można podzielić na usługi magazynowania na warunkach ciągłych oraz usługi magazynowania gazu na warunkach przerywanych. Usługi magazynowania gazu na warunkach ciągłych gwarantują dostawy gazu bez względu na warunki rynkowe i dlatego są znacząco droższe $\left(389,1 \mathrm{zł} / 1000 \mathrm{~m}{ }^{3}\right)$ od usług przerywanych $\left(107,5 \mathrm{z} / 1000 \mathrm{~m}^{3}\right)$. Tak znacząca różnica w kosztach wynika między innymi z tego, że na bazie usługi ciągłej można ustanowić zapas obowiązkowy, wymagany od importerów gazu prowadzących działalność w Polsce. W publikacji przedstawiono konsekwencje szybkiego wzrostu ilości importowanego gazu. Wzrost ten wpłynął na rosnącą wielkość zapasu obowiązkowego. W latach 2017-2019 wzrosła ona o około 56\% (z 8,5 TWh do 13 TWh). W związku z tym parametry budowy przyszłego PMG powinny uwzględniać bieżące warunki rynkowe. Duża różnica pomiędzy kosztami usług magazynowych ma znaczący wpływ na przychody z usług magazynowania gazu. W związku z tym procedura określania najkorzystniejszych parametrów pracy PMG powinna uwzględniać nie tylko ograniczanie kosztów budowy i eksploatacji magazynów gazu, ale również maksymalizację przychodów z usług magazynowania. W związku z tym parametry budowy przyszłego PMG powinny uwzględniać bieżące warunki rynkowe. W celu określenia preferowanych parametrów budowy i eksploatacji podziemnych magazynów gazu przeprowadzono analizę budowy nowego PMG w przykładowym sczerpanym złożu gazu ziemnego. Obliczenia wykonano dla pięciu wybranych różnych wielkości pojemności czynnej. Dla każdej pojemności czynnej przeprowadzono obliczenia dla trzech czasów sczerpania całej pojemności (80, 100 i 120 dni). Następnie wykonano analizę finansową różnych wariantów budowy nowego PMG, opierając się na wskaźniku NPV i wskaźniku jednostkowego kosztu budowy i eksploatacji pojemności czynnej. Analiza finansowa wykazała, że w obecnej sytuacji rynkowej bardziej opłaca się budować „,szybki” magazyn gazu, o stosunkowo krótkim czasie odbioru i zatłaczania pojemności czynnej.
\end{abstract}

Słowa kluczowe: podziemny magazyn gazu (PMG), rynek gazu w Polsce, usługi magazynowe, gaz ziemny.

ABSTRACT: The publication deals with the problem of adjusting UGS operation parameters to changes in the Polish natural gas system. It was emphasized that the demand for active storage capacity directly results from the volume of domestic consumption of natural gas and the structure of gas supply to the market. The bar chart shown in Figure 1 presents gas consumption in Poland, broken down into domestic production and imports for 1995-2018. The presented chart confirmed the fast increase in gas demand in recent years in Poland. In addition, the graph showed that since 2012, domestic natural gas production has been systematically falling from 4.3 to 3.8 billion $\mathrm{m}^{3}$. Therefore, the growing demand for gas is met by additional gas imports. In 2018, the volume of natural gas import was around 14.5 billion $\mathrm{m}^{3}$. Currently, approximately $79 \%$ of total gas consumption in Poland is covered by import. The article emphasized that rapidly growing gas import generates

Autor do korespondencji: B. Filar, e-mail: bogdan.filar@inig.pl

Artykuł nadesłano do Redakcji: 30.12.2019 r. Zatwierdzono do druku: 27.08.2020 r. 
demand for new UGS working capacities. The main purpose of the publication was to find the answer to the question of which parameters of underground gas storage are preferred by the gas market in Poland. The costs of providing gas storage services in Poland were analyzed in order to determine the desired UGS parameters. The analysis showed a large difference between the costs of providing firm and interruptible storage services in Poland. Firm storage services guarantee gas supplies irrespective of market conditions and are therefore significantly more expensive (PLN 389.1/1000 $\mathrm{m}^{3}$ ) than interruptible services (PLN 107.5/1000 $\mathrm{m}^{3}$ ). The main reason for such a significant cost difference is because firm services can be used to establish a mandatory reserve, required by law in Poland. The article indicates the consequences of a rapid growing natural gas import trend. The increase of gas import volume results in a large increase of mandatory reserve volume. In 2017-2019, the amount of mandatory reserves increased by about 56\% (from 8.5 to $13 \mathrm{TWh}$ ). Therefore, the construction parameters of the future UGS should take into account current market conditions. The large difference between the costs of storage services has a significant impact on revenues from gas storage services. Therefore, the procedure for determining the most favorable operating parameters of UGS should take into account not only the reduction of storage, construction and operation costs of gas storage facilities, but also the optimization of revenues from gas storage services. Therefore, the construction parameters of the future UGS should take into account current market conditions. In order to determine the preferred parameters for the construction and operation of underground gas storage facilities, an analysis of the construction of a new UGS in an exemplary depleted natural gas field was carried out. Calculations were made for five different active capacities. For each active capacity, calculations were made for three times of full capacity exhaustion (80, 100 and 120 days). Then, financial analysis was carried out for several variants of the construction of the new UGS based on the NPV index and the cost of construction and operation of active capacity. Financial analysis has shown that in the current market situation it is more profitable to build, a "fast" gas storage with a relatively short time of withdrawal and injection of working volume.

Key words: underground gas storage (UGS), natural gas market in Poland, storage services, natural gas.

\section{Rosnąca rola PMG w krajowym systemie gazowniczym}

Podziemne magazyny gazu są niezbędnym składnikiem każdego systemu gazowniczego (Sharples, 2016). Zapotrzebowanie na pojemność czynną magazynów bezpośrednio wynika z krajowego zużycia gazu ziemnego oraz ze struktury dostaw gazu na rynek. Rysunek 1 prezentuje zużycie gazu w Polsce w rozbiciu na wydobycie krajowe i import. Analizując wykres zużycia gazu w Polsce w latach 1995-2018, można zauważyć szybki wzrost zapotrzebowania na gaz w ostatnich latach. Dodatkowo wykres pokazuje, że począwszy od 2012 roku krajowe wydobycie gazu ziemnego systematycznie spadało - z wielkości 4,3 mld $\mathrm{m}^{3}$ do $3,8 \mathrm{mld}^{3}$. W związku z tym rosnące zapotrzebowanie na gaz jest zaspokajane dodatkowym jego importem. W roku 2018 wielkość importu gazu ziemnego wynosiła około $14,5 \mathrm{mld} \mathrm{m}^{3}$. Obecnie około $79 \%$ całkowitego zużycia gazu pokrywane jest importem.

Należy pamiętać o tym, że wielkość importu jest dość stała w czasie, dlatego znaczący skok zapotrzebowania na gaz przeważnie bilansowany jest przez dostawy gazu z podziemnych magazynów gazu (Creti, 2009; Sharples, 2016). Analiza stopnia wykorzystania magazynów gazu zlokalizowanych w Polsce pokazuje całkowite wykorzystanie pojemności czynnych w kilku ostatnich latach (rys. 2). Wykres przedstawia dostępną pojemność czynną, stan napełnienia magazynów oraz wielkość zapasu obowiązkowego alokowanego w PMG. Można zauważyć, że pomimo rozbudowy pojemności czynnej z 1,6 $\mathrm{mld} \mathrm{m}^{3}$ do $3 \mathrm{mld} \mathrm{m}^{3}$ obecnie cała pojemność czynna - na co wskazuje stan napełnienia magazynów - jest wykorzystywana w 100\%. Należy podkreślić również, że „handlowa” pojemność czynna dostępna z roku na rok jest pomniejszona o zapas obowiązkowy, który w trzech ostatnich latach znacząco wzrósł.

Na szczególną uwagę zasługuje fakt, że wielkość zapasu obowiązkowego w latach 2017-2019 wzrosła o około 56\% (z 8,5 TWh do 13 TWh). Sytuacja ta wyjaśnia szybko rosnący import gazu oraz świadczy o braku rezerw pojemności magazynowej. Prognozowany przyrost zapotrzebowania na pojemność czynną PMG w Polsce można zaspokoić poprzez budowę nowych obiektów lub rozbudowę istniejących. Czas potrzebny do budowy nowego lub rozbudowy istniejącego PMG wynosi co najmniej 5-7 lat. Z drugiej strony należy pamiętać o tym, że okres eksploatacji PMG to co najmniej 40-50 lat. W związku

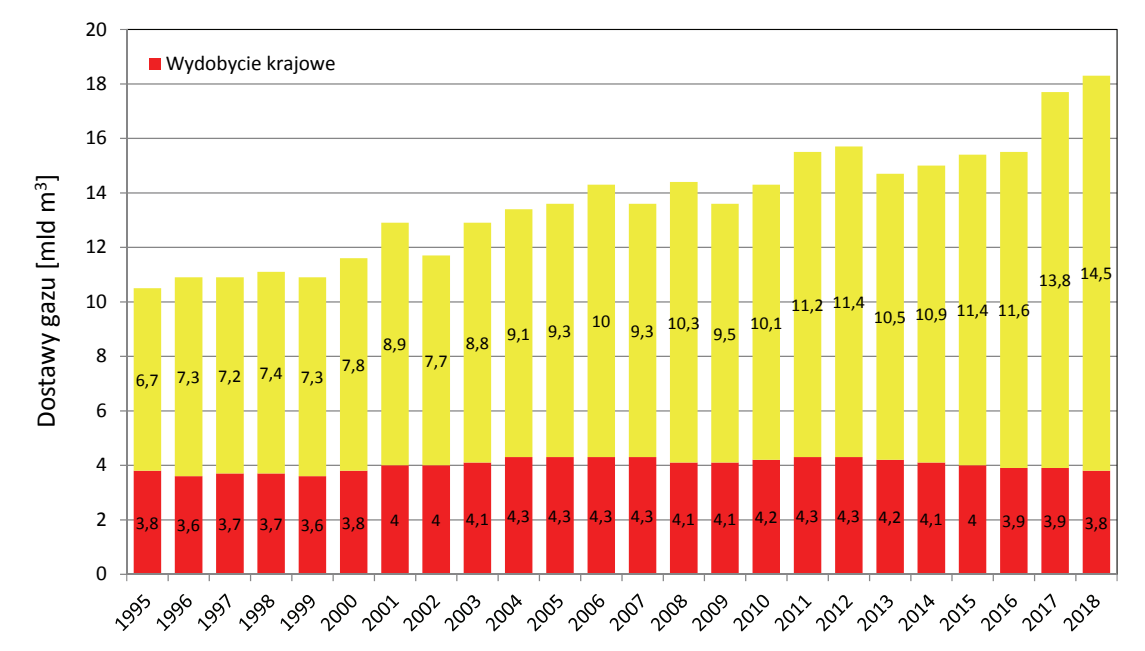

Rys. 1. Struktura dostaw gazu ziemnego w Polsce w latach 1995-2018, obliczenia własne INiG - PIB

Fig. 1. Structure of natural gas supply in Poland in years 1995-2018, own calculations INIiG - PIB 


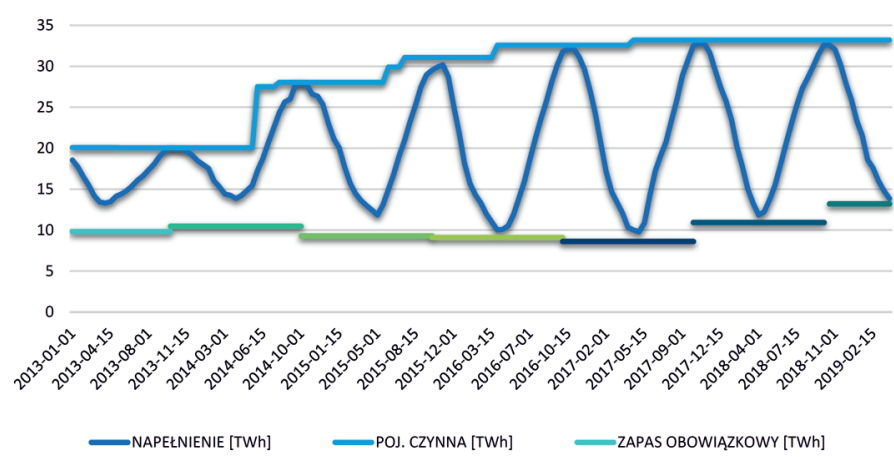

Rys. 2. Wykres wykorzystania pojemności magazynowych w Polsce (Urząd Regulacji Energetyki, 2019)

Fig. 2. Graph of storage capacity utilization in Poland (Urząd Regulacji Energetyki, 2019)

z tym decyzja inwestycyjna dotycząca budowy nowego lub rozbudowy istniejącego PMG powinna zostać poprzedzona analizą opłacalności ekonomicznej jego budowy i eksploatacji (Paliński, 2016, 2018). Głównym celem niniejszej publikacji jest udzielenie odpowiedzi na pytanie, jakie parametry powinien posiadać nowy magazyn gazu. Odpowiednia analiza została wykonana dla budowy i eksploatacji magazynu wytworzonego w sczerpanym złożu gazu ziemnego.

\section{Koszty świadczenia usług magazynowych w Polsce}

W Polsce jedyną firmą posiadającą koncesję na bezzbiornikowe magazynowanie gazu ziemnego jest Gas Storage Poland Sp. z o.o. Zgodnie z dyrektywą UE firma Gas Storage Poland została wydzielona z PGNiG SA do świadczenia usług magazynowania gazu. Jak każda firma GSP prowadzi działalność gospodarczą, w związku z tym musi być dochodowa. Wszystkie usługi magazynowania gazu można podzielić na dwa główne rodzaje:

- usługi ciągłe;

- usługi przerywane.

Usługa magazynowania na warunkach ciągłych gwarantuje świadczenie usług bez względu na warunki rynkowe. Dlatego usługa ciągła jest podstawą utworzenia zapasu obowiązkowego. Natomiast usługa przerywana magazynowania gazu to usługa, która może zostać ograniczona lub nawet przerwana w zależności od sytuacji występującej na rynku. W związku z tym, że usługa ciągła jest gwarantowana, to jej koszt jest wyższy niż usługi przerywanej. GSP Sp. z o.o. na swojej stronie internetowej zamieściła kalkulator ceny usług magazynowych, dzięki któremu można wyliczyć koszt ich świadczenia zarówno dla PMG złożowych, jak i kawernowych (KPMG). W związku z tym, że artykuł dotyczy magazynów wytworzonych w złożach sczerpanych, to w dalszej analizie uwzględniono koszt zakupu usług magazynowych w GSP Sp. z o.o. dla PMG Wierzchowice (tabela 1).
Tabela 1. Cena magazynowania gazu w PMG Wierzchowice

Table 1. Price of gas storage services at UGS Wierzchowice

\begin{tabular}{|c|c|c|}
\hline PMG & Rodzaj usługi & $\begin{array}{c}\text { Koszt magazynowania } \\
{\left[\mathbf{z l} / \mathbf{1 0 0 0} \mathbf{~ m}^{\mathbf{3}}\right]}\end{array}$ \\
\hline \hline Wierzchowice & ciągła & 389,1 \\
\hline Wierzchowice & przerywana & 107,5 \\
\hline
\end{tabular}

Podsumowując, osiągnięcie prognozowanych przychodów dla przykładowego projektu PMG obliczono na podstawie cen usług oferowanych przez GSP Sp. z o.o., w tym usługi ciągłej i przerywanej (Gray i Khandelwal, 2004; Hodges, 2004).

\section{Podstawowe parametry pracy podziemnego magazynu gazu}

Każdy podziemny magazyn gazu ziemnego charakteryzuje się określonymi parametrami budowy i eksploatacji. Do podstawowych parametrów pracy magazynu można zaliczyć:

- pojemność całkowitą;

- pojemność czynną i buforową;

- zakres ciśnień pracy;

- ciśnienie odbioru;

- liczbę odwiertów;

- moc stacji sprężania gazu.

Analiza poszczególnych parametrów pracy magazynu jest trudna, ponieważ wszystkie parametry są ze sobą ściśle powiązane. Zmiana jednych parametrów ma bezpośredni wpływ na wartości pozostałych. W związku z tym odpowiednia analiza finansowa musi uwzględniać wszystkie wymienione parametry.

\section{Określenie optymalnych parametrów pracy nowego PMG}

Dotychczasowa praktyka budowy podziemnych magazynów gazu koncentrowała się na wytworzeniu odpowiednich pojemności czynnych oraz wydajności zatłaczania i odbioru gazu. Początkowo właścicielami PMG były koncerny paliwowe, które posiadały oddziały poszukiwawcze, wiertnicze, eksploatacyjne, przesyłowe i magazynowania gazu. W związku z tym, że dział magazynowania gazu był częścią dużego koncernu, to koszty wytworzenia oraz eksploatacji magazynów gazu odgrywały rolę drugoplanową. Liberalizacja rynku gazowniczego spowodowała, zgodnie z dyrektywami UE, wydzielenie z koncernów firm świadczących usługi magazynowe (Gas Storage Poland Sp. z o.o.). W dobie liberalizacji rynku gazowniczego koszty świadczenia usług magazynowych zaczynają odgrywać coraz większą rolę. Firmy zarządzające 
PMG i posiadające w swoich portfelach magazyny gazu charakteryzujące się niskimi kosztami świadczenia usług mogą zawierać konkurencyjne kontrakty. Należy podkreślić to, że firmy świadczące usługi magazynowania gazu muszą optymalizować przychody przy równoczesnym ograniczaniu kosztów. Jak już wcześniej stwierdzono, optymalizacja parametrów pracy PMG jest procesem złożonym, gdyż wymaga przeprowadzenia szeregu analiz wielu parametrów, które są ze sobą wzajemnie powiązane. Dotychczas głównym celem optymalizacji pracy podziemnych magazynów gazu było takie dobranie: - wielkości pojemności czynnej;

- wielkości buforu niezbędnego do eksploatacji magazynu;

- liczby odwiertów eksploatacyjnych oraz

- mocy stacji kompresorów,

aby koszt magazynowania $1 \mathrm{~m}^{3}$ pojemności czynnej był jak najniższy (Parsons, 2013; Safarov i Colin, 2017). Rosnący udział energii odnawialnej w bilansie energetycznym kraju wymusza dostosowanie się rynku źródeł konwencjonalnych, w tym rynku PMG, do nowych wyzwań (Li, 2007; Kosowski et al., 2013). Aktualnie występuje bardzo dynamiczna zmiana na europejskim rynku usług magazynowych, która polega na preferowaniu szybkich usług ciągłych, to znaczy usług, które zapewniają ciągłość dostaw. W związku z tym, że źródła energii OZE nie są stabilne, gdyż wiatr czasami nie wieje, a słońce czasami nie świeci, to wzrasta zapotrzebowanie na energię pochodzącą z elektrowni gazowych. Rosnące zapotrzebowanie na usługi ciągłe przyczynia się do dużego zróżnicowania cen usług ciągłych i przerywanych (Boogert i De Jong, 2008; Bjerksund et al., 2011). Dobrym tego przykładem jest koszt usług oferowanych przez GSP Sp. z o.o. (tabela 1). Oczywiście sytuacja ta ma znaczący wpływ na przychody z usług magazynowania gazu (Chen i Forsyth, 2006; Mastrangelo, 2007). W związku z tym procedura określenia najkorzystniejszych parametrów pracy PMG powinna uwzględniać nie tylko ograniczanie kosztów budowy i eksploatacji, ale również maksymalizację przychodów z usług magazynowania (Mann i Ayala, 2009; Warin, 2012). W celu pokazania wpływu parametrów budowy i eksploatacji PMG na oczekiwane zyski z inwestycji wykonano obliczenia dla budowy i eksploatacji przykładowego PMG.

\section{Parametry złoża gazu ziemnego oraz założenia inwestycyjne budowy PMG}

Do analizy ekonomicznej wybrano złoże gazu ziemnego, którego pierwotne zasoby geologiczne wynosiły $2500 \mathrm{mln} \mathrm{m}^{3}$. Pierwotne ciśnienie złożowe miało wartość Pds =14,0 MPa. Horyzont gazonośny posiada miąższość wynoszącą $18 \mathrm{~m}$. Porowatość skały zbiornikowej to $20 \%$, natomiast średnia wielkość przepuszczalności jest równa $150 \mathrm{mD}$. Złoże jest obecnie eksploatowane sześcioma odwiertami, pozostało w nim $310 \mathrm{mln} \mathrm{m}^{3}$ gazu, a jego ciśnienie złożowe wynosi $\mathrm{Pds}=2,0 \mathrm{MPa}$. Podstawowe parametry przykładowego złoża przedstawiono w tabeli 2.

Tabela 2. Podstawowe parametry przykładowego PMG

Table 2. Basic parameters of the exemplary UGS

\begin{tabular}{|l|c|}
\cline { 2 - 2 } \multicolumn{1}{l|}{} & PMG \\
\hline \hline Pierwotne zasoby geologiczne Go [mln m $\left.{ }^{3}\right]$ & 2500 \\
\hline Pierwotne ciśnienie złożowe [MPa] & 14,0 \\
\hline Miąższość horyzontu gazonośnego [m] & 18 \\
\hline Porowatość skały zbiornikowej [\%] & 20 \\
\hline Przepuszczalność skały zbiornikowej [mD] & 150 \\
\hline Aktualny stan zasobów geologicznych [mln m $\left.{ }^{3}\right]$ & 310 \\
\hline Aktualny stan ciśnienia złożowego Pds [MPa] & 2,0 \\
\hline Liczba odwiertów [sztuk] & 6 \\
\hline
\end{tabular}

\section{Założenia przyjęte do budowy PMG}

Budowa PMG wymaga doprecyzowania podstawowych parametrów pracy projektowanego magazynu. Do podstawowych parametrów eksploatacyjnych magazynu można zaliczyć wielkość pojemności czynnej i buforowej magazynu oraz maksymalną moc zatłaczania i odbioru gazu do/z PMG. Zmiana pojemności czynnej wymaga zmiany zakresu ciśnień eksploatacji magazynu oraz zmiany parametrów instalacji napowierzchniowej, w tym stacji sprężania gazu. W celu przeprowadzenia analizy optymalizacyjnej przyjęto następujące założenia: - pojemność czynna Va będzie zmieniać się w przedziale 1500-1130 $\mathrm{mln} \mathrm{m}^{3}$;

- pojemność buforowa Vb będzie zmieniać się w przedziale 1000-1370 mln $\mathrm{m}^{3}$;

- górne ciśnienie magazynowania gazu będzie wynosić 14,0 MPa;

- dolne ciśnienie pracy PMG będzie zawarte w przedziale 6,0-8,0 MPa;

- zainstalowana stacja sprężania gazu będzie pracować podczas fazy odbioru i zatłaczania;

- maksymalne ciśnienie tłoczenia wyniesie 15,5 MPa;

- zakres ciśnień w gazociągu systemowym w punkcie zdawczo-odbiorczym (PZO) będzie równy 4,0-8,0 MPa;

- czas sczerpania pojemności czynnej Todb wyniesie 80, 100 i 120 dni;

- $\quad$ czas zatłaczania pojemności czynnej Tzat = 150 dni;

- depresja eksploatacji odwiertów będzie wynosić 20\% ciśnienia złożowego;

- liczba odwiertów zostanie określona na podstawie czasu sczerpania pojemności czynnej. 


\section{Analiza parametrów pracy przykładowego PMG, część techniczno-złożowa}

Doboru najkorzystniejszych parametrów pracy projektowanego PMG dokonano na podstawie analizy finansowej (De Jong, 2015). Wykonanie analizy finansowej wymagało określenia podstawowych parametrów pracy projektowanego magazynu wraz z wszystkimi składnikami magazynu wpływającymi zarówno na koszty, jak i na później uzyskiwane przychody. W związku z tym analiza optymalizacyjna została przeprowadzona $\mathrm{w}$ dwóch etapach:
- w pierwszym etapie określono podstawowe parametry PMG (Va, Vb, liczbę odwiertów, zakres ciśnień pracy PMG, moc odbioru i zatłaczania, moc stacji sprężania gazu, wielkość pojemności handlowej, wielkość zapasu) (Kwilosz, 2011);

- w drugim obliczono wskaźniki analizy finansowej (JKPC, JKPCE, NPV).

Wyniki obliczeń - wykonanych dla pięciu wariantów - wielkości parametrów złożowych i napowierzchniowych projektowanego PMG niezbędnych do wykonania analizy finansowej przedstawiono $\mathrm{w}$ tabeli 3 .

Tabela 3. Podstawowe parametry projektowanego PMG

Table 3. Basic parameters of the designed new UGS

\begin{tabular}{|c|c|c|c|c|c|c|}
\hline Parametr & Jednostka & Wariant 1 & Wariant 2 & Wariant 3 & Wariant 4 & Wariant 5 \\
\hline Pdsd & {$[\mathrm{MPa}]$} & 6,00 & 6,50 & 7,00 & 7,50 & 8,00 \\
\hline $\mathrm{Vb}$ & {$\left[\mathrm{mln} \mathrm{m}^{3}\right]$} & 1000,00 & 1090,00 & 1180,00 & 1280,00 & 1370,00 \\
\hline $\mathrm{Va}$ & {$\left[\mathrm{mln} \mathrm{m}^{3}\right]$} & 1500,00 & 1410,00 & 1320,00 & 1220,00 & 1130,00 \\
\hline Pdsg & {$[\mathrm{MPa}]$} & 14,00 & 14,00 & 14,00 & 14,00 & 14,00 \\
\hline Pdssr & {$[\mathrm{MPa}]$} & 10,00 & 10,25 & 10,50 & 10,75 & 11,00 \\
\hline qodwśr & {$\left[\mathrm{m}^{3} / \mathrm{min}\right]$} & 518,41 & 533,51 & 548,65 & 563,82 & 579,02 \\
\hline ilodwt80 & [sztuk] & 25,00 & 23,00 & 21,00 & 19,00 & 17,00 \\
\hline ilodwt100 & [sztuk] & 20,00 & 19,00 & 17,00 & 15,00 & 14,00 \\
\hline ilodwt120 & [sztuk] & 17,00 & 16,00 & 14,00 & 12,56 & 11,29 \\
\hline Pss & {$[\mathrm{MPa}]$} & 4,80 & 5,20 & 5,60 & 6,00 & 6,40 \\
\hline qPMG80odb & {$\left[\mathrm{m}^{3} / \mathrm{min}\right]$} & 7064,98 & 7116,65 & 7078,96 & 6957,05 & 6755,51 \\
\hline qPMG100odb & {$\left[\mathrm{m}^{3} / \mathrm{min}\right]$} & 5651,98 & 5693,32 & 5663,17 & 5565,64 & 5404,41 \\
\hline qPMG120odb & {$\left[\mathrm{m}^{3} / \mathrm{min}\right]$} & 4709,99 & 4744,44 & 4719,31 & 4638,03 & 4503,67 \\
\hline Ptłodb & {$[\mathrm{MPa}]$} & 8,00 & 8,00 & 8,00 & 8,00 & 8,00 \\
\hline qZat & {$\left[\mathrm{m}^{3} / \mathrm{min}\right]$} & 5547,21 & 5212,37 & 4873,51 & 4530,63 & 4183,75 \\
\hline Pzat & {$[\mathrm{MPa}]$} & 15,50 & 15,50 & 15,50 & 15,50 & 15,50 \\
\hline Moc80 & {$[\mathrm{kW}]$} & 11558,00 & 7958,00 & 6712,00 & 5540,00 & 4604,00 \\
\hline Moc100 & {$[\mathrm{kW}]$} & 9246,00 & 6366,00 & 5369,00 & 4432,00 & 3683,00 \\
\hline Moc120 & {$[\mathrm{kW}]$} & 7705,00 & 5305,00 & 4474,00 & 3693,00 & 3069,00 \\
\hline MocZatł & {$[\mathrm{kW}]$} & 18178,00 & 17081,00 & 15564,00 & 14469,00 & 13361,00 \\
\hline Vciągłe80 & {$\left[\mathrm{mln} \mathrm{m}^{3}\right]$} & 573,00 & 561,61 & 538,08 & 509,73 & 476,56 \\
\hline Vciągłe100 & {$\left[\mathrm{mln} \mathrm{m}^{3}\right]$} & 430,00 & 416,18 & 393,06 & 385,36 & 377,66 \\
\hline Vciągłe120 & {$\left[\mathrm{mln} \mathrm{m}^{3}\right]$} & 350,00 & 333,91 & 311,65 & 324,17 & 289,01 \\
\hline
\end{tabular}

Objaśnienia przyjętego nazewnictwa parametrów przedstawionych w tabeli:

Pdsd, Pdssr, Pdsg - ciśnienie złożowe pracy PMG: dolne, średnie i górne;

Va - pojemność czynna;

$\mathrm{Vb}$ - pojemność buforowa;

qodwśr - średnia wydajność odwiertu;

ilodwt80, ilodwt100, ilodwt120 - liczba odwiertów eksploatacyjnych niezbędnych do sczerpania pojemności czynnej PMG w czasie 80,100 i 120 dni;

Pss - dolne ciśnienie pracy stacji sprężania gazu;

qPMG80odb, qPMG100odb, qPMG120odb - wydajność PMG obliczona dla dolnego ciśnienia pracy magazynu, dla czasu odbioru wynoszącego odpowiednio 80, 100 i 120 dni;

Ptłodb - maksymalne ciśnienie tłoczenia gazu w czasie fazy odbioru;

Pzat - maksymalne ciśnienie tłoczenia gazu w czasie fazy zatłaczania;

qZat - wydajność tłoczenia gazu podczas fazy zatłaczania obliczona dla górnego ciśnienia pracy PMG;

Moc80, Moc100, Moc120 - moc stacji sprężania gazu niezbędna do sczerpania pojemności czynnej PMG w czasie 80, 100 i 120 dni;

MocZatł - moc stacji sprężania gazu niezbędna do zatłoczenia pojemności czynnej PMG w czasie 150 dni;

Vciągłe80, Vciągłe100, Vciągłe120 - wielkość zapasu obowiązkowego (usługi ciągłej), jaką będzie można alokować w PMG, którego czas sczerpania wynosi 80,100 i 120 dni. 
Można zauważyć, że dla dolnego ciśnienia pracy magazynu $\mathrm{Pds}_{\mathrm{d}}=6,0 \mathrm{MPa}$ pojemność czynna PMG wyniesie $1500 \mathrm{mln} \mathrm{m}^{3}$, natomiast pojemność buforowa $-1000 \mathrm{mln}^{3}$, przy założeniu górnego ciśnienia pracy magazynu wynoszącego 14,0 MPa. Liczba odwiertów eksploatacyjnych dla tej pojemności czynnej zmienia się w przedziale 25-17, w zależności od czasu sczerpania całej pojemności czynnej (80, 100 i 120 dni). Dodatkową bardzo istotną informacją jest to, że w przypadku wykonania 25 odwiertów eksploatacyjnych w PMG można będzie utworzyć zapas obowiązkowy (usługa ciągła) w ilości $573 \mathrm{mln} \mathrm{m}^{3}$ (Todb $=80$ dni). W wariancie Todb $=120$ dni zapas obowiązko-

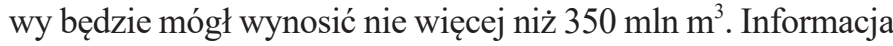
o wielkości zapasu obowiązkowego jest cenna, ponieważ cena usługi ciągłej wynosi $389,1 \mathrm{zł} / 1000 \mathrm{~m}^{3}$, podczas gdy cena usługi przerywanej to $107,5 \mathrm{zl} / 1000 \mathrm{~m}^{3}$.

\section{Finansowa analiza opłacalności budowy i eksploatacji PMG w przykładowym złożu}

Analizowane warianty budowy PMG charakteryzują się różną pojemnością czynną, buforową, zakresem ciśnień pracy, różną liczbą odwiertów oraz różną mocą stacji sprężania gazu. Wymienione parametry mają wpływ na wielkość kosztów budowy i eksploatacji PMG. W związku z tym do oceny kosztów wytworzenia i eksploatacji poszczególnych wariantów zdecydowano się wykorzystać trzy wskaźniki analizy finansowej:

- JKPC - wskaźnik jednostkowego kosztu wytworzenia pojemności czynnej,

- JKPC = suma nakładów inwestycyjnych/suma pojemności czynnej,

- obie wartości są wielkościami zdyskontowanymi liczonymi do czasu uzyskania projektowanej pojemności czynnej;

- JKPCE - wskaźnik jednostkowego kosztu budowy i eksploatacji pojemności czynnej,

- JKPCE = suma nakładów inwestycyjnych i operacyjnych/ suma pojemności czynnej, obie wartości zdyskontowane liczone dla określonego czasu;

- NPV - finansowa wartość zaktualizowana netto dla inwestycji.

Pierwszy wskaźnik, JKPC, umożliwia porównanie opłacalności inwestycji różnych wariantów tego samego projektu lub różnych projektów. Wskaźnik JKPCE daje przybliżony minimalny koszt świadczenia usług magazynowych, przy założonej stopie dyskonta. Natomiast wskaźnik NPV pokazuje opłacalność inwestycji przy aktualnych cenach świadczenia usług magazynowych (ciągłych i przerywanych).

Wykonanie odpowiednich obliczeń wymagało przyjęcia następujących założeń:
- stopa dyskonta: $8 \%$;

- nakłady ponoszone przez 6 lat;

- okres obliczeń: 25 lat;

- koszt gazu buforowego: $1 \mathrm{z} / / \mathrm{m}^{3}$;

- koszt odwiertu z wyposażeniem oszacowany na $15 \mathrm{mln}$ zł;

- koszt budowy stacji sprężania gazu 6375 zz/1kW;

- koszt budowy gazociągu łączącego PMG z systemem gazowniczym: $20 \mathrm{mln}$ zł;

- stawki amortyzacji zgodne z obecnie obowiązującą ustawą.

\section{Szacunkowa analiza kosztów budowy PMG}

Obliczenia zostały wykonane dla wszystkich wartości pojemności czynnej przedstawionych w tabeli 3. Oszacowane nakłady inwestycyjne dla budowy PMG o pojemności czynnej wynoszącej $\mathrm{Va}=1130 \mathrm{mln} \mathrm{m}^{3}$ przedstawiono $\mathrm{w}$ tabeli 4 .

Wykonane obliczenia pokazały, że szacunkowy koszt budowy PMG o pojemności czynnej $1130 \mathrm{mln}^{3}$ wyniesie około $1720 \mathrm{mln}$ zł. Należy podkreślić, że największe nakłady inwestycyjne konieczne są na wytworzenie buforu, gdyż analizowane złoże jest sczerpane w $88 \%$. W związku z tym wytworzenie wymaganego buforu będzie wymagało zatłoczenia

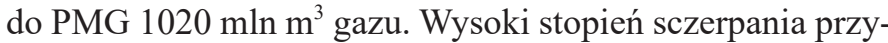
kładowego złoża odpowiada obecnej sytuacji złóż krajowych, których stopień sczerpania jest bardzo wysoki.

Tabela 4. Szacunkowe koszty budowy PMG dla pojemności czynnej wynoszącej $1130 \mathrm{mln} \mathrm{m}^{3}$

Table 4. Estimated construction costs of UGS for the working capacity of 1130 million $\mathrm{m}^{3}$

\begin{tabular}{|l|c|c|c|}
\hline \multirow{2}{*}{$\begin{array}{c}\text { Budowa PMG o pojemności } \\
\text { czynnej 1130 } \text { mln m }^{3}\end{array}$} & $\begin{array}{c}\text { Koszt } \\
\text { jednost. }\end{array}$ & $\begin{array}{c}\text { Liczba/ } \\
\text { wielkość }\end{array}$ & $\begin{array}{c}\text { Koszt } \\
\text { calkowity }\end{array}$ \\
\cline { 2 - 4 } & [tys. zl] & & [tys. zl] \\
\hline \hline $\begin{array}{l}\text { Koszt zakupu gruntów, badań } \\
\text { i dokumentacji projektowej }\end{array}$ & & & 68000 \\
\hline $\begin{array}{l}\text { Wiercenie odwiertów }+ \\
\text { wyposażenie }\end{array}$ & $\begin{array}{c}15000 / \\
\text { odw. }\end{array}$ & 25 & 255000 \\
\hline $\begin{array}{l}\text { Budowa instalacji } \\
\text { napowierzchniowej }\end{array}$ & & & 272000 \\
\hline Budowa tłoczni & $1 / 1000 \mathrm{~m}^{3}$ & 1020000 & 1020000 \\
\hline $\begin{array}{l}\text { Budowa gazociągu łączącego } \\
\text { PMG z systemem }\end{array}$ & & & 1720000 \\
\hline Wytworzenie buforu & & & 20000 \\
\hline Razem & & & \\
\hline
\end{tabular}

\section{Szacunkowa analiza kosztów operacyjnych funkcjonowania PMG}

Koszty działalności operacyjnej (bez amortyzacji) wynikają z szacunkowych obliczeń uwzględniających koszty występujące 
na polskich magazynach gazu ziemnego. Prognoza kosztów przedstawiona w tabeli 5 została wykonana dla budowy PMG o pojemności czynnej równej $1130 \mathrm{mln}^{3}$, jednakże analogiczne obliczenia przeprowadzono dla pozostałych pojemności czynnych. Koszty operacyjne zostały podzielone na koszty zmienne i stałe. Do kosztów zmiennych zależnych od ilości gazu zatłoczonego/odebranego zaliczono koszty energii elektrycznej (praca sprężarek), opłaty eksploatacyjnej i ubezpieczenia majątku. Pozostałe koszty zaliczono do kosztów stałych. Obliczenie kosztów operacyjnych eksploatacji PMG wymagało przyjęcia następujących założeń:

- koszty zmienne:

- energia elektryczna - określono szacunkowo: 3 zł/1000 $\mathrm{m}^{3}$ poj. czynnej;

- opłata eksploatacyjna: 0,9 zł/1000 m³ poj. czynnej;

- ubezpieczenia majątku: 1,00 zł/1000 m³ poj. czynnej;

- koszty stałe:

- wynagrodzenia - określono szacunkowo: $3 \mathrm{mln}$ zł/rok;

- koszt obsługi instalacji napowierzchniowej: $3 \mathrm{mln}$ zł/rok;

- obsługa odwiertów: $2,8 \mathrm{mln} \mathrm{z}$ /rok.

Zestawienie rocznych kosztów eksploatacji magazynu przedstawiono w tabeli 5.

Przeprowadzone obliczenia wykazały, że roczny koszt operacyjny funkcjonowania magazynu o pojemności czynnej $1130 \mathrm{mln} \mathrm{m}^{3}$ będzie wynosił około 14,34 $\mathrm{mln}$ zł.

Dane przedstawione w tabeli 5 zostały wykorzystane do wykonania analizy finansowej dla każdego zestawu pojemności czynnej i buforowej. Obliczenia dla każdej określonej pojemności czynnej zostały przeprowadzone dla trzech czasów sczerpania PMG (80, 100 i 120 dni). Wskaźniki analizy finansowej JKPC, JKPCE i NPV obliczone dla wszystkich pojemności czynnych przedstawiono w tabeli 6 . Wyniki obliczeń zostały również zaprezentowane na rysunkach 3-5. Analizując rysunek 3, można zauważyć, że najdroższa jest budowa magazynu, którego czas odbioru całej pojemności czynnej wynosi 80 dni. Rysunek 4 potwierdza, że najtańsze koszty świadczenia usług magazynowania gazu będą występowały w przypadku budowy magazynu o najdłuższym czasie sczerpania, wynoszącym 120 dni. Niestety wydłużenie okresu sczerpania PMG spowoduje ograniczenia mocy wydobywczych potrzebnych do eksploatacji magazynu. W związku z tym zmniejszy się również wielkość usługi ciągłej, jaką można będzie świadczyć w danym PMG. Główną wadą tego rozwiązania jest zmniejszenie oczekiwanych przychodów z usług magazynowych. Rysunek 5 potwierdza, że najtańszy magazyn będzie generował najniższe NPV, natomiast najdroższy PMG wygeneruje najwyższy zwrot z inwestycji. Należy podkreślić, że wszystkie obliczenia miały charakter szacunkowy.

Wykonana analiza wyraźnie wykazała, że w obecnej sytuacji rynkowej bardziej opłaca się budować „,szybki” magazyn gazu, o stosunkowo krótkim czasie odbioru i zatłaczania pojemności czynnej.

Tabela 5. Koszty operacyjne dla pojemności czynnej $1130 \mathrm{mln} \mathrm{m}^{3}$ Table 5. Operating costs for the active capacity of 1,130 million $\mathrm{m}^{3}$

\begin{tabular}{|c|c|}
\hline $\begin{array}{l}\text { Koszty operacyjne dla pojemności czynnej } \\
\qquad 1130 \mathrm{mln} \mathrm{m}^{3}\end{array}$ & $\begin{array}{l}\text { Koszt } \\
\text { [tys. zl] }\end{array}$ \\
\hline \multicolumn{2}{|l|}{ Koszty zmienne } \\
\hline Energia elektryczna & 3390,00 \\
\hline Opłata eksploatacyjna & 1017,00 \\
\hline Ubezpieczenie majątku & 1130,00 \\
\hline Suma kosztów zmiennych & 5537,00 \\
\hline \multicolumn{2}{|l|}{ Koszty stałe } \\
\hline Wynagrodzenia & 3000,00 \\
\hline Obsługa instalacji napowierzchniowej & 3000,00 \\
\hline Obsługa odwiertów & 2800,00 \\
\hline Suma kosztów stałych & 8800,00 \\
\hline
\end{tabular}

Tabela 6. Wskaźniki analizy finansowej JKPC, JKPCE i NPV

Table 6. JKPC, JKPCE and NPV financial analysis indicators

\begin{tabular}{|c|c|c|c|c|c|c|}
\hline Parametr & Jednostka & Wariant 1 & Wariant 2 & Wariant 3 & Wariant 4 & Wariant 5 \\
\hline \hline Va & {$\left[\mathrm{mln} \mathrm{m}^{3}\right]$} & 1500,00 & 1410,00 & 1320,00 & 1220,00 & 1130,00 \\
\hline Vb & {$\left[\mathrm{mln} \mathrm{m}^{3}\right]$} & 1000,00 & 1090,00 & 1180,00 & 1280,00 & 1370,00 \\
\hline JKPC_80 & {$\left[\mathrm{z} / 1000 \mathrm{~m}^{3}\right]$} & 1484,34 & 1517,13 & 1554,40 & 1610,21 & 1661,15 \\
\hline JKPC_100 & {$\left[\mathrm{z} / 1000 \mathrm{~m}^{3}\right]$} & 1338,75 & 1393,23 & 1422,05 & 1467,01 & 1545,20 \\
\hline JKPC_120 & {$\left[\mathrm{z} / 1000 \mathrm{~m}^{3}\right]$} & 1251,40 & 1300,30 & 1322,78 & 1395,41 & 1467,90 \\
\hline JKPCE_80 & {$\left[\mathrm{z} / 1000 \mathrm{~m}^{3}\right]$} & 148,23 & 151,91 & 156,09 & 162,20 & 167,90 \\
\hline JKPCE_100 & {$\left[\mathrm{z} / 1000 \mathrm{~m}^{3}\right]$} & 134,64 & 140,34 & 143,74 & 148,84 & 157,08 \\
\hline JKPCE_120 & {$\left[\mathrm{z} / 1000 \mathrm{~m}^{3}\right]$} & 126,49 & 131,67 & 134,47 & 142,15 & 149,87 \\
\hline NPV_80 & {$[$ tys. zł] } & 504525,68 & 401576,53 & 443460,43 & 472939,10 & 487766,28 \\
\hline NPV_100 & {$[$ tys. zł] } & 406106,83 & 305970,79 & 316023,25 & 343910,35 & 337677,06 \\
\hline NPV_120 & {$[$ tys. zł] } & 356286,64 & 286390,47 & 264611,49 & 265071,83 & 262021,68 \\
\hline
\end{tabular}


PMG Przykład

Wykres wskaźnika kosztów budowy $1 \mathrm{~m}^{3}$ pojemności czynnej (JKPC), obliczony dla 80, 100 i 120 dni sczerpania pojemności projektowanego PMG

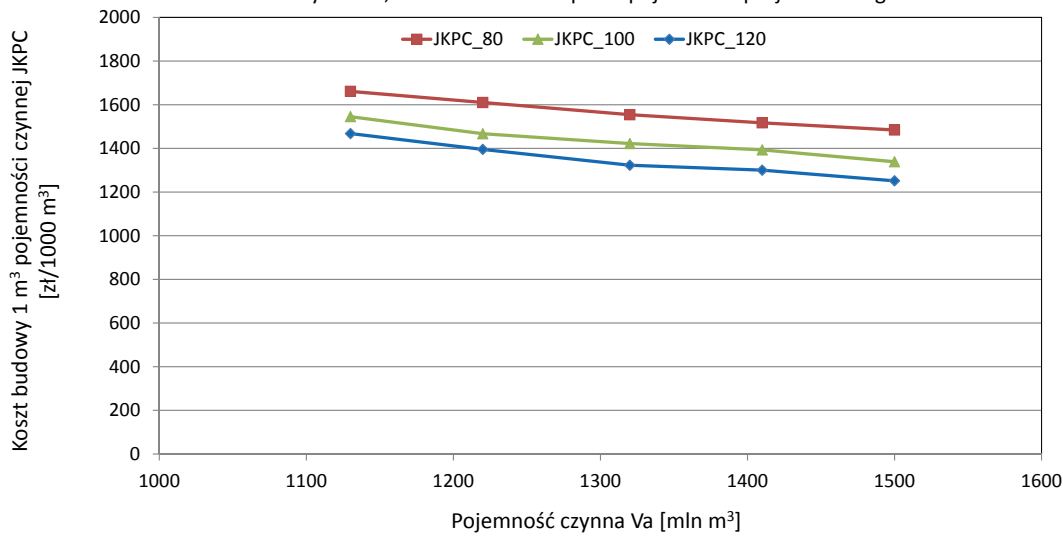

Rys. 3. Wykres wskaźnika jednostkowego kosztu budowy i eksploatacji pojemności czynnej JKPCE

Fig. 3. A graph presenting the unit cost of construction and operation of active capacity, JKPCE

PMG Przykład

Wykres wskaźnika kosztów budowy i eksploatacji $1 \mathrm{~m}^{3}$ pojemności czynnej (JKPCE) obliczony dla 80, 100 i 120 dni sczerpania pojemności projektowanego PMG

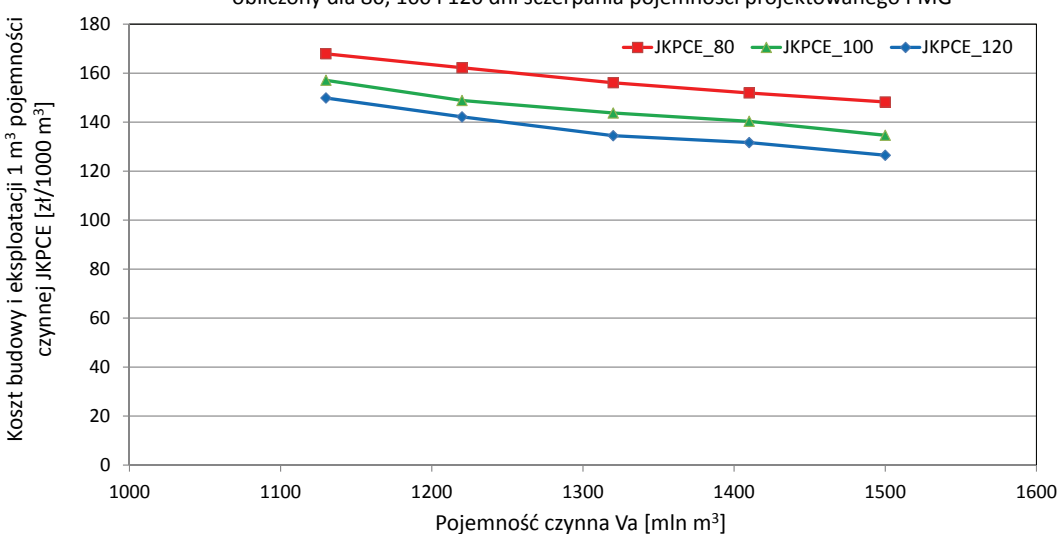

Rys. 4. Wykres wskaźnika jednostkowego kosztu budowy i eksploatacji pojemności czynnej JKPCE

Fig. 4. A graph presenting the unit cost for the construction and operation of active capacity, JKPCE

PMG Przykład

Wykres wartości bieżącej netto inwestycji NPV, obliczonej dla 80, 100 i 120 dni sczerpania pojemności czynnej projektowanego PMG

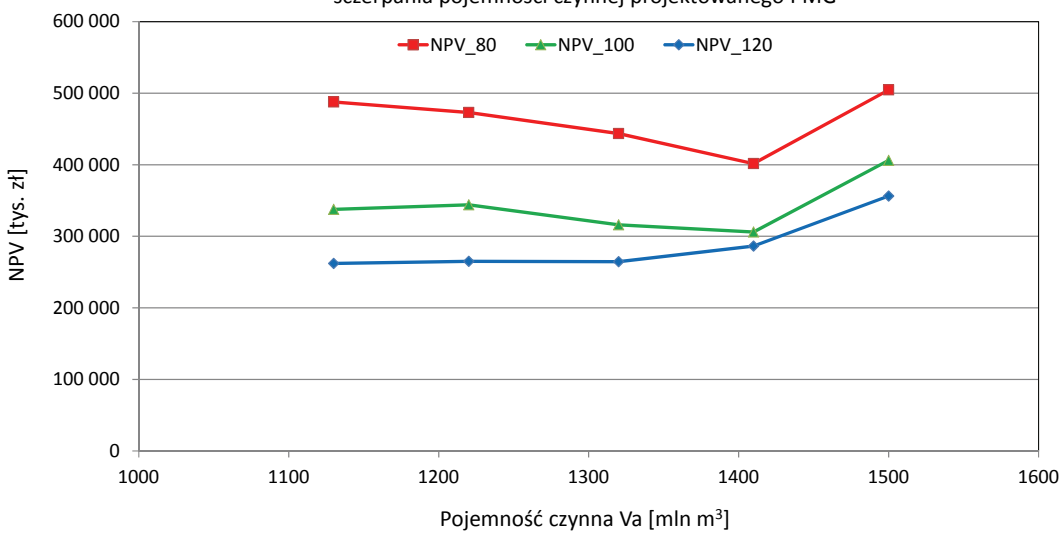

Rys. 5. Wykres bieżącej wartości netto obliczonej dla inwestycji

Fig. 5. NPV values calculated for the investment

\section{Podsumowanie i wnioski}

W publikacji poruszono problem dostosowania parametrów eksploatacji PMG do zmian zachodzących w polskim systemie gazowniczym. W pracy zwrócono szczególną uwagę na rosnący import gazu, który w 2018 roku wynosił $14,5 \mathrm{mld} \mathrm{m}^{3}$. Podkreślono, że szybko rosnący import gazu generuje zapotrzebowanie na nowe pojemności czynne PMG. Natomiast przeprowadzona analiza wykazała dużą rozbieżność pomiędzy kosztami świadczenia poszczególnych usług magazynowania gazu. Usługa magazynowania na warunkach ciągłych, gwarantująca dostawy gazu bez względu na warunki rynkowe, jest dużo droższa $\left(389,1 \mathrm{z} ł / 1000 \mathrm{~m}^{3}\right)$ od usługi przerywanej $\left(107,5 \mathrm{z}\right.$ z/1000 $\left.\mathrm{m}^{3}\right)$. W związku z tym parametry budowy przyszłego PMG powinny uwzględniać bieżące warunki rynkowe. W celu wykazania optymalnych parametrów budowy i eksploatacji PMG przeprowadzono analizę budowy nowego PMG w przykładowym sczerpanym złożu gazu ziemnego. Obliczenia wykonano dla pięciu wybranych różnych wielkości pojemności czynnej. Dla każdej pojemności czynnej przeprowadzono obliczenia dla trzech czasów sczerpania całej pojemności czynnej (80, 100 i 120 dni). Następnie wykonano analizę finansową dla analizowanych wariantów budowy nowego PMG w oparciu o trzy wskaźniki analizy finansowej.

Wykonana analiza pozwala na wyciągnięcie następujących wniosków:

- najdroższa jest budowa magazynu, którego czas odbioru całej pojemności czynnej wynosi 80 dni;

- najtańsze koszty świadczenia usług magazynowania gazu będą występowały przy budowie magazynu o najdłuższym czasie sczerpania pojemności czynnej, wynoszącym 120 dni;

- wydłużenie okresu sczerpania PMG spowoduje ograniczenia mocy wydobywczych potrzebnych do eksploatacji magazynu, które zmniejszą możliwości świadczenia usług ciągłych (alokacji zapasu obowiązkowego);

- najtańszy magazyn będzie generował najniższe NPV, natomiast najdroższy PMG wygeneruje najwyższy zwrot z inwestycji;

- w obecnej sytuacji rynkowej, przy rosnącym w bilansie energetycznym udziale OZE, 
preferowane będą PMG o krótkich czasach sczerpania i zatłoczenia pojemności czynnej.

Należy podkreślić, że wszystkie obliczenia miały charakter szacunkowy. Wykonana analiza wyraźnie wykazała, że w obecnej sytuacji rynkowej bardziej opłaca się budować „szybki” magazyn gazu, o stosunkowo krótkim czasie odbioru i zatłaczania pojemności czynnej.

Artykuł powstał na podstawie pracy statutowej pt. Opracowanie metodyki pozwalającej na optymalizację kosztów świadczenia ustug magazynowania gazu - praca INiG - PIB na zlecenie MNiSW; nr zlecenia: 0038/KP/2019, nr archiwalny: DK-4100-0028/2019.

\section{Literatura}

Bjerksund P., Gunnar S., Vagstad F., 2011. Gas storage valuation: Price modelling v. optimization methods. The Energy Journal, 32: 203-27.

Boogert A., De Jong C., 2008. Gas storage valuation using a Monte Carlo method. The Journal of Derivatives, 15: 81-98.

Chen Z., Forsyth P., 2006. Stochastic Models of Natural Gas Prices and Applications to Natural Gas Storage Valuation. Working Paper, David R. Cheriton, School of Computer Science, University of Waterloo.

Creti A., 2009. Gas storage in Europe: Toward a market-oriented approach. The Economics of Natural Gas Storage, Wyd. SpringerVerlag, Berlin: 1-12.

De Jong C., 2015. Gas storage valuation and optimization. Journal of Natural Gas Science and Engineering, 24, Suppl. C: 365-378.

Gray J., Khandelwal P., 2004. Towards a realistic gas storage model. Commodities Now, 7: 1-4.

Hodges S.D., 2004. The value of a Storage Facility. Working Paper, Warwick Business School, University of Warwick.

Kosowski P., Stopa J., Rychlicki S., 2013. Prognozowanie zapotrzebowania na podziemne magazynowanie gazu w Polsce na tle sytuacji bieżącej i scenariuszy rozwoju rynku gazowego. Rynek Energii, 5: 117-123.

Kwilosz T., 2011. Zastosowanie metody statystycznej do oszacowania zapasu strategicznego PMG, z uwzględnieniem niepewności wyznaczenia parametrów pracy systemu gazowniczego. Nafta-Gaz, 3: 192-197.

Li Y., 2007. Natural Gas Storage Valuation. Master Thesis, Georgia Institute of Technology: 1-63.

Mann A.W., Ayala L.F., 2009. Intelligent Design and Modelling of Natural Gas Storage Facilities. International Journal of Modelling and Simulation, 29(2): 214-223. DOI: 10.1080/02286203.2009.11442527.

Mastrangelo E., 2007. An Analysis of Price Volatility in Natural Gas Markets. U.S. Energy Information Administration, Washington.
Paliński A., 2016. Eksploracja danych w prognozowaniu cen gazu i usług magazynowania gazu. X Międzynarodowa Konferencja Naukowo-Techniczna. Geopetrol 2016. Prace Naukowe Instytutu Nafty i Gazu - Państwowego Instytutu Badawczego, 209: 857-861.

Paliński A., 2018. Hurtownie danych i eksploracja danych w prognozowaniu popytu na gaz i usługi magazynowania gazu. Nafta-Gaz, 4: 283-289. DOI: 10.18668/NG.2018.04.04.

Parsons C., 2013. Quantifying natural gas storage optionality: A twofactor tree model. Journal of Energy Markets, 6: 95-124.

Safarov N., Colin A., 2017. Natural gas storage valuation and optimization under time-inhomogeneous exponential Lévy processes. International Journal of Computer Mathematics, 94: 2147-65.

Sharples J.D., 2016. The importance of gas storage facilities in the European gas and power markets. International Journal of Environmental Studies, 73(3): 369-378. DOI: 10.1080/00207233.2016.1165482.

Urząd Regulacji Energetyki, 2019. Sprawozdanie z działalności Prezesa URE w $2018 \mathrm{r}$.

Warin X., 2010. Gas storage hedging. [W:] Carmona R.A., Del Moral P., Hu P., Oudjane N. (eds.). Numerical Methods in Finance. Springer Proceedings in Mathematics Vol. 12. Springer, BerlinHeidelberg: 421-445.

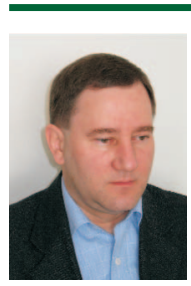

Mgr inż. Bogdan FILAR

Kierownik Zakładu Podziemnego

Magazynowania Gazu

Instytut Nafty i Gazu - Państwowy Instytut Badawczy ul. Lubicz 25 A

31-503 Kraków

E-mail: bogdan.filar@inig.pl

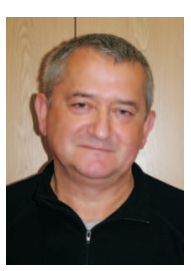

Mgr Mariusz MIZIOŁEK

Starszy specjalista badawczo-techniczny w Zakładzie

Podziemnego Magazynowania Gazu

Instytut Nafty i Gazu - Państwowy Instytut Badawczy ul. Lubicz $25 \mathrm{~A}$

31-503 Kraków

E-mail: mariusz.miziolek@inig.pl

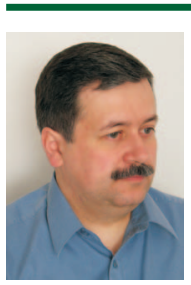

Dr Tadeusz KWILOSZ

Adiunkt w Zakładzie Podziemnego

Magazynowania Gazu

Instytut Nafty i Gazu - Państwowy Instytut Badawczy

ul. Lubicz 25 A

31-503 Kraków

E-mail: tadeusz.kwilosz@inig.pl 